\title{
Contribution of Emotional Intelligence to Peer Acceptance on Students at Public Junior High School 14 Surakarta
}

\author{
Muhammad Rizky Nur Prakoso* \\ Graduate Program \\ Universitas Negeri Yogyakarta \\ Yogyakarta, Indonesia \\ muh.rizkynp@gmail.com*
}

\author{
Muh Farozin \\ Guidance and Counseling Department \\ Universitas Negeri Yogyakarta \\ Yogyakarta, Indonesia \\ farozin2311@yahoo.com
}

\begin{abstract}
This study aims to describe the level of peer acceptance among students at Public Junior High School 14 Surakarta, the level of emotional intelligence of the students, and the contribution of emotional intelligence to peer acceptance. This study used a quantitative descriptive approach conducted at Public Junior High School 14 Surakarta. The sample of this study consisted of 143 students. The sampling technique used a simple random sampling technique. Data collection techniques in this study used a questionnaire with a Likert scale. The data were analyzed using the Test, which is formulated with One Tailed Test analysis for the first and second hypotheses. For the third hypothesis, a simple linear regression techniques used to analyze the data and assisted by IBM SPSS Statistics 23 software. The results showed that the level of peer acceptance classified in the low category, the level of emotional intelligence of students classified in the high category, and the level of emotional intelligence that contributes to the level of peer acceptance.
\end{abstract}

Keywords-peer acceptance, emotional intelligence, junior high school

\section{INTRODUCTION}

Humans are creatures that have a high level of intelligence compared to other living creatures. Humans tend to always grow and develop according to their growth period. Humans will adapt to their environment to grow and develop. Santrock [1] stated that individuals in their teens period will face an experience changes in their biological, cognitive, social and emotional development. One of the tasks of adolescent development is that individuals are able to interact and socialize among their peers to establish relationships with others [2]. Prayitno [3] revealed that self-adjustment is the initial step for adolescents to foster a relationship between peers, therefore the social role will emerge, both from boys and girls. By understanding the role of each individual in the social environment, it will create a reciprocal relationship that is harmonious and as expected.

Padmomartono [4] claimed that obstacles and difficulties are things that are faced by adolescents in their development. However, in dealing with it, some adolescents can get through it well without become a negative identity as a form of defense mechanism. The process of forming adolescent identity is influenced by how adolescents learn to understand themselves first. The intensity of adolescent gathering time is the most with peers compared to their parents at home, so the learning process of adolescents is very dependent on how they place themselves in their peer environment $[5,6]$.

Peer groups are children or adolescents who have the same age range or maturity level [1]. The interaction received by adolescents in dealing with peer groups can be a positive thing that affects their personality. Mappiare [7] stated that the acceptance of adolescents by their peers is one of the needs that must be met by adolescents, in addition to the needs associated with parents. Peer acceptance referred to an individual assessment to be accepted and chosen by people around him/her to be members in a certain group or a clique [8]. Therefore, peer acceptance are able to have a positive impact on adolescents as seen from the social-emotional, personal, and academic aspects of school as a stage of adolescent development $[9,10]$.

One of the factors influencing an adolescents to be accepted by their peers is their personality, about how ther ability to control and manage their emotional intelligence or not. Goleman [11] claimed that emotional intelligence is a person's ability to recognize feelings, motivate themselves, and manage emotions in establishing relationships with others. In the process of making a relationship, there are two emotional tendencies that need to be considered by the person, include the inability to control anger and the inability to develop an attitude of not being shy, afraid, and anxious in making relationships [12].

Uno [13] explained that the role of emotional intelligence in adolescents had a positive impact on academic achievement, another benefit of emotional intelligence as the source of energy, a source of encouragement, and the most powerful spirit in our self. With emotional intelligence, adolescents have more broad insight because it is based on feelings and has the potential to benefit them in solving their problems. Good management of emotional intelligence tends to have a positive impact in choosing alternative solutions to problems that do not harm various parties [14]. However, lack of emotional intelligence will allow someone to take shortcuts or take easy ways, because he/she does not consider any things either in him/herself or the people around him/her [15]. Guidance and Counseling Services in schools have the vision to help and facilitate students to solve their problems independently, both in the fields of learning, personal, social, and career. Guidance and Counseling Services can also provide prevention against problems with students, School counselors are able to conduct needs assessments. 
That's assessment through sociometric assessments to find out social relationships between students who are involved in and outside the classroom [16, 17]. Through information services, the School counselors can provide an understanding of how to manage emotional intelligence within oneself, develop social skills, and apply emotional intelligence skills to form a relationship with student peers/clique [18]. Therefore, the role of the school counselors in guiding students is very necessary, besides assisting students in providing Guidance and Counseling services, the school counselors can make observations about student development, in terms from the cognitive, affective, and psychomotor aspects of students [19].

Based on the observations and interviews with a number of students at Public Junior High School 14 Surakarta, the researcher obtained information about how students' emotional intelligence was thought to affect the acceptance of their peers, viewed from daily life, both when in the classroom during lessons, and when outside of class hours. Further information obtained through observation and reconnaissance, about 20-30 students showed a lack of mastery in terms of emotional intelligence. Some students who are less active because they feel different from their classmates, some students experience less self-confidence when gathering with classmates outside school hours, there were students who tended to be alone and less interacting with their friends, the emergence of groups/clique between students which causes that some students feel isolated in class because they feel unacceptable in these groups/clique, the presence of students with negative or distorted behavior at school due to unstable emotional stated, and some other juvenile delinquency both in class and outside the classroom.

\section{METHODS}

This study was conducted on 143 of eighth grades students of Public Junior High School 14 Surakarta, using quantitative descriptive analysis methods, with a correlation study. The sampling technique used a simple random sampling technique. Data collection techniques in this study used 2 questionnaires, those are emotional intelligence questionnaires and peer acceptance questionnaires, with a modified Likert scale in the form of four possible answer choices. Analysis of the data used to test the first and the second hypotheses, both used a T-test which is assisted using a One-Tailed Test analysis. The third hypothesis used a simple linear regression technique assisted by IBM SPSS Statistics 23 software.

\section{RESULT AND DISCUSSION}

Result

The Peer Acceptance $(P A)$ data and the Emotional Intelligence $(E I)$ data both obtained using the questionnaires instrument (Peer Acceptance questionnaire and Emotional Intelligence questionnaire) consisted of 143 respondents. Analysis of these data assisted by IBM SPSS Statistics 23 software. The first and second hypotheses were obtained by the One-Tailed Test analysis, and the third hypothesis obtained by using a simple linear regression for obtaining the level of contribution of emotional intelligence to peer acceptance on eighth-grade students at Public Junior High School 14 Surakarta. The results of this study showed the first hypothesis result followed by the second and the third hypothesis result, here are the results:

The results of the study began with the table of the descriptive quantitative result about Peer Acceptance and Emotional Intelligence, showed that the data collected from the 143 respondents contained any important data, here is the table of descriptive statistic data of this study:

Table 1. Descriptive Statistic from Both Variables

\begin{tabular}{|l|l|l|}
\hline & $\begin{array}{l}\text { Peer Acceptance } \\
(\mathrm{Y})\end{array}$ & Emotional Intelligence (X) \\
\hline Mean & 73,22 & 85,76 \\
\hline Standard Deviation & 5,478 & 5,627 \\
\hline Lowest Score & 52 & 69 \\
\hline Highest Score & 90 & 101 \\
\hline \multicolumn{2}{|l|}{$\mathrm{N}=143$} \\
\hline
\end{tabular}

According from the table I, the result showed that the Mean from each variables obtained different amount, which are the peer acceptance variable obtained 73,22 and the emotional intelligence variable obtained 85,76 . The standard deviation from peer acceptance variable obtained 5,478 and the emotional intelligence variable obtained 5,627. Lowest score from each variables obtained 52 and 69, meanwhile the highest score from each variables are 90 and 101 . Following to the table of descriptive statistic above, the data analyzed to categorizing the level of peer acceptance (Y) and the level of emotional intelligence (X). here are the data categorizing:

Table 2. Categorizing Peer Acceptance Scores

\begin{tabular}{|c|c|c|c|}
\hline Categories & Criteria & Frequency & Percentage (\%) \\
\hline $52-73$ & Low & 74 & $51,75 \%$ \\
\hline $74-90$ & High & 69 & $48,25 \%$ \\
\hline \multicolumn{2}{r}{ Total } & 143 & $100 \%$ \\
\hline
\end{tabular}

The results of categorizing Peer Acceptance scores (Y) in table II described that scores with high criteria lie at intervals of 74-90, while low criteria scores lie at intervals of 52-73. So it can be said that from 143 respondents, students who have peer acceptance with low criteria are obtained as many as 74 students $(51.75 \%)$, while students who achieved peer acceptance with high criteria were 69 students $(48.25 \%)$. Therefore, it can be concluded that students with peer acceptance scores are classified as "low level". To answer the formulation of the first hypothesis in this study ("The level of peer acceptance in students is high level"), there were some procedures to be considered.

Table 3. One Tailed Test for the First Hypothesis

\begin{tabular}{|c|c|c|c|c|c|c|}
\hline & \multicolumn{9}{|c|}{ Test Value $=0$} \\
\cline { 2 - 7 } & & & & & \multicolumn{2}{c|}{$\begin{array}{c}\text { 95\% Confidence } \\
\text { Interval of the } \\
\text { Vifference }\end{array}$} \\
\cline { 4 - 7 } Var & $T$ & $d f$ & $\begin{array}{c}\text { Sig. (2- } \\
\text { tailed) }\end{array}$ & $\begin{array}{c}\text { Mean } \\
\text { Diffe- } \\
\text { rence }\end{array}$ & Lower & Upper \\
\hline PA & 1.593 & 142 & .000 & 73.196 & 72.29 & 74.10 \\
\hline
\end{tabular}

The data analyzed using One Tailed Test and assisted by IBM SPSS Statistics 23 software. The scores of $\mathrm{df}=\mathrm{n}$ $1,143-1=142$. So T-table with df in the amount of 142 , with an error rate of $5 \%$ obtained T-table by 1.656 . T-table knew based on the percentage point distribution of " $\mathrm{t}$ ", if $\mathrm{df}$ known as $142(\mathrm{df}=\mathrm{n}-1)$, then the T-table were 1.656. The calculation result of the T-score obtained 1.593. 
The first hypothesis was tested using Tscore and Ttable, if Tscore $>\mathrm{T}$-table, then the first hypothesis was accepted. From the calculation of independent sample T-test, T-score were smaller than T-table $(1.593<1.656)$, so it could be concluded that the first hypothesis in this study was rejected, and it could be said that student peer acceptance was relatively low.

Furthermore, Emotional Intelligence $(E I)$ data obtained using the Emotional Intelligence questionnaire instrument with the same respondent in the amount of 143 respondents. Analysis of these data assisted by IBM SPSS Statistics 23 software. The following data are:

Table 4. Categorizing Emotional Intelligence Scores

\begin{tabular}{|c|c|c|c|}
\hline Categories & Criteria & Frequency & Percentage (\%) \\
\hline $69-85$ & Low & 32 & $22,37 \%$ \\
\hline $86-101$ & High & 101 & $77,63 \%$ \\
\hline Total & & 143 & $100 \%$ \\
\hline
\end{tabular}

The results of categorizing the Emotional Intelligence score $(\mathrm{X})$ in table IV described that the scores with the high criteria lie at intervals of 86-110, while the low criteria scores lie at intervals of 69-85. So, it could be said that from 143 respondents, students who have emotional intelligence with low criteria are obtained as 32 students (22.37\%), while students who achieve emotional intelligence with high criteria are 101 students (77.63\%). Then it can be concluded that students with emotional intelligence scores are classified as "high level". To answer the second hypothesis in this study ("The level of emotional intelligence in students is classified as a high level"), there were some procedures to be considered, same as the analyzed methods for the first hypothesis, and also assisted by IBM SPSS Statistics 23 software.

Table 5. One Tailed Test for the Second Hypothesis

\begin{tabular}{|c|c|c|c|c|c|c|}
\hline \multirow{10}{*}{ Var } & \multicolumn{9}{|c|}{ Test Value $=0$} \\
\cline { 5 - 7 } & & $T$ & $d f$ & $\begin{array}{c}\text { Sig. (2- } \\
\text { tailed) }\end{array}$ & $\begin{array}{c}\text { Mean } \\
\text { Diffe- } \\
\text { rence }\end{array}$ & $\begin{array}{c}\text { 95\% Confidence } \\
\text { Interval of the } \\
\text { Difference }\end{array}$ \\
\hline EI & 1.823 & 142 & .000 & 85.762 & 84.83 & 86.69 \\
\hline
\end{tabular}

According for the table $\mathrm{V}$, the df value was the same as the first hypothesis measurement, which is in the amount of 142 , and the T-table used were 1.656. The calculation result of T-score obtained 1,823, so, it could be said that T-score was greater than Ttable $(1,823>1,656)$. Then, it could be concluded that the second hypothesis in this study was acceptable, and it could be said that the emotional intelligence of students was relatively high. The third hypothesis tested using a Simple Linear Regression test. From the results of data processing assisted by IBM SPSS Statistics 23 software, data obtained are presented in the following table:
Table 6. Correlation Analysis

\begin{tabular}{|l|l|l|l|}
\hline \multicolumn{4}{|c|}{ Correlations } \\
\hline \multirow{2}{*}{$\begin{array}{l}\text { Peer } \\
\text { Acceptance }\end{array}$} & $\begin{array}{c}\text { Peer } \\
\text { Acceptance }\end{array}$ & $\begin{array}{c}\text { Emotional } \\
\text { Intelligence }\end{array}$ \\
\cline { 2 - 4 } & $\begin{array}{l}\text { Pearson } \\
\text { Correlation }\end{array}$ & 1 & $.397^{* *}$ \\
\cline { 2 - 4 } & Sig. (2-tailed) & & .000 \\
\cline { 2 - 4 } & $N$ & 143 & 143 \\
\hline $\begin{array}{l}\text { Emotional } \\
\text { Intelligence }\end{array}$ & $\begin{array}{l}\text { Pearson } \\
\text { Correlation }\end{array}$ & $.397^{* *}$ & 1 \\
\hline
\end{tabular}

Based on the results of correlation analysis, the probability value between peer acceptance and emotional intelligence was 0,000. If the p-value < 0.05 , then Ho was rejected and $\mathrm{Ha}$ automatically was accepted. This study obtained a p-value of 0,000 , whereas $0,000<0.05$, so it could be concluded that the Ha ("The level of emotional intelligence of students contributes to the level of peer acceptance") was accepted.

To find out the level of the contribution of emotional intelligence (variable X) towards peer acceptance (variable Y) can be resulted with the following steps: 1) regression equation and, 2) analysis of contribution variable $X$ to variable $\mathrm{Y}$. The regression equation are presented in the following table:

Table 7. Regression Equation

\begin{tabular}{|c|c|c|c|c|c|c|}
\hline \multicolumn{7}{|c|}{ Coefficients $^{\mathrm{a}}$} \\
\hline \multirow{2}{*}{\multicolumn{2}{|c|}{ Model }} & \multicolumn{2}{|c|}{$\begin{array}{l}\text { Unstandardized } \\
\text { Coefficients }\end{array}$} & \multirow{2}{*}{$\begin{array}{r}\text { Standa-rdized } \\
\text { Coeffi-cients } \\
\text { Beta }\end{array}$} & \multirow[t]{2}{*}{$\mathrm{t}$} & \multirow[t]{2}{*}{ Sig. } \\
\hline & & B & $\begin{array}{c}\text { Std. } \\
\text { Error }\end{array}$ & & & \\
\hline \multirow[t]{2}{*}{1} & (Constant) & 39.65 & 6.550 & & 6.054 & .000 \\
\hline & $E I$ & .408 & .079 & .397 & 5.135 & .000 \\
\hline \multicolumn{7}{|c|}{ a. Dependent Variable: $P A$} \\
\hline
\end{tabular}

The results of testing the regression equation between the variables of emotional intelligence $(\mathrm{X})$ with peer acceptance (Y) showed a significance level of 0,000 less than 0.05 , which means that if the p-value < sig. then Ho is rejected and $\mathrm{Ha}$ is accepted. So it can be concluded that there is a contribution of emotional intelligence $(\mathrm{X})$ to peer acceptance (Y) on students at Public Junior High School 14 Surakarta. The regression line equation is obtained for:

$\mathrm{Y}=\mathrm{a}+\mathrm{bX}$

$\mathrm{Y}=39,657+0,408 \mathrm{X}$

The regression line equation is obtained $\mathrm{Y}=39,657+$ $0,408 \mathrm{X}$, which means that if variable $\mathrm{X}$ (emotional intelligence) increasing by one unit, then the variable $Y$ (peer acceptance) will increase by 0.408 units.Meanwhile the next step to obtain the level of the contribution of variable $\mathrm{X}$ to variable $\mathrm{Y}$ can be seen in the following table. 
Table 7. Contribution of Variable X to Variable Y

\begin{tabular}{|c|c|c|c|c|}
\hline \multicolumn{5}{|c|}{ Model Summary } \\
\hline Model & $R$ & $R$ Square & $\begin{array}{c}\text { Adjusted } R \\
\text { Square }\end{array}$ & $\begin{array}{c}\text { Std. Error of the } \\
\text { Estimate }\end{array}$ \\
\hline 1 & $.397^{\text {a }}$ & .158 & .152 & 5.046 \\
\hline \multicolumn{5}{|l|}{ a. Predictors: (Constant), Emotional Intelligence } \\
\hline \multicolumn{4}{|l|}{ b. Dependent Variable: Peer Acceptance } \\
\hline
\end{tabular}

Based on the table 4 , the contribution of variable $X$ (emotional intelligence) to variable Y (peer acceptance) could be described that the value of $\mathrm{R}$ Square was 0.158 , so the contribution of the variable emotional intelligence $(\mathrm{X})$ to the variable peer acceptance $(\mathrm{Y})$ in amount of $15.8 \%$, while the rest is influenced by other variables. Calculation of the contribution of variable $\mathrm{X}$ to variable $\mathrm{Y}$ proved that the third hypothesis in this study was accepted, which is the level of emotional intelligence of students contributing to the level of acceptance of their peers, and its contribution was $15.8 \%$. Discussion

This research was conducted with the aim to describe the level of student peer acceptance, the level of emotional intelligence of students, as well as to determine the contribution of emotional intelligence to peer acceptance in the level of class VIII (eighth-grade) at Public Junior High School 14 Surakarta. The first hypothesis formulation in this study is "The level of student's peer acceptance in the level of class VIII at Public Junior High School 14 Surakarta is high". Based on data analysis, it is known that the level of peer acceptance is classified as low criteria, which is $51.75 \%$. While the level of emotional intelligence is classified as high criteria with a percentage value of $77.63 \%$. So from the results of the analysis, it is known that the level of emotional intelligence contributes by $15.8 \%$ to the level of student peer acceptance.

Categorizing the results at the level of student peer acceptance were classified as low level, the data illustrated the situation of someone who tends to feel rejected by his/her peers so that it can hamper his/her development in the social environment they live [1]. Some things that cause low-level acceptance of one's peers include lack of recognition from others, lack of caring, lack of a sense of togetherness between peers, lack of mutual assistance and intimacy in establishing relationships [20]. Other factors that cause individuals to feel unaccepted by their peers that cause a low level of peer acceptance are lack of maintenance of interaction or communication, some people who choose selfishness, lack of enthusiasm or enthusiasm from people around, lack of confidence, and some other negative attitudes that cause selfactualization inhibited. Someone who gets negative treatment tends to be alone and avoids meeting with his/her friends.

The low level of peer acceptance could be caused by a number of things, from observations at the Public Junior High School 14 Surakarta, there are some students tend to form their own groups, while students who have some limitations cannot interact properly because they are not part of any groups/clique. When working in groups, the teachers divide the groups freely so that each student is allowed to form their own workgroups, this makes the chances of students being accepted by their peers to be small (difficult to make a relationships with others), because he/she feels his/her presence is not considered by his/her classmates concerned with members of his/her own group rather than allowing others to join them. The school counselor can be said to pay less attention to the level of peer acceptance, due to the lack of service delivery that focuses on group activities, so that students' actualization to implement group-based activities is less developed.

The state of the emotional brain that exists in humans is an internal factor that greatly influences the development of one's emotional intelligence [11]. This means that from within humans there are internal factors that greatly affect a person in developing emotional intelligence. These skills do not grow by themselves, but it needs training and seriousness in practice [21]. Without proper training and direction, it is not impossible that students' emotional intelligence tends to be poor and cause obstacles in achieving optimal development.

The results showed that most of the students have high emotional intelligence, the high emotional intelligence possessed by students showed that students have characteristics as individuals who have abilities in terms of self-understanding, self resource management, emotional control, participating in feeling or empathy, and fostering social relationships with others [13]. In addition, students who are able to develop emotional intelligence are able to more easily establish social relationships, form good independence, manage selfconfidence, and develop leadership attitudes that can be applied in fostering social relationships with peers.

Based on observations at the Public Junior High School 14 Surakarta, high emotional intelligence was due to the provision of appropriate services from the school counselors. The provision of services provided helps students to be more independent and skilled in developing emotional intelligence. In addition, the implementation of the development of students' emotional intelligence was monitored by the school counselor, so that if students experience difficulties, the school counselor could help or facilitate students to solve their problems by themselves. Another possibilities that make a high level of emotional intelligence were guidance from students' parents, with good parenting about controlling and managing emotions by parents, it could reflect a behavior that looks more capable and calm when they interacting with other students, both during lessons and outside class hours [22].

The second hypothesis formulation in this study is "The level of student's emotional intelligence Public Junior High School 14 Surakarta is classified as high". The results showed that most of the eighth-grade students of Public Junior High School 14 Surakarta had high-level emotional intelligence with a percentage reaching $77.63 \%$ (111 out of 143 students), the rest were classified as low with a percentage of $22.37 \%$ (32 students). The high-level emotional intelligence possessed by eighth-grade students of Public Junior High School 14 Surakarta shows that students have characteristics as individuals who have abilities in terms of self- understanding, management of self-resources, emotional control, participating in feeling or empathy, and fostering social relationships with others.

Emotional intelligence remains a factor in student acceptance by peers, although, from the results, the contribution of emotional intelligence to peer acceptance was only $15.8 \%$. People who are intelligent in controlling their emotions will be able to live in a peaceful, comfortable, and happy life because they are able to recognize and manage emotions in themselves, so their attitudes and behavior can be controlled [23]. People with good emotional intelligence can develop their ability to break away from moods that make them uncomfortable such as 
anger, sadness, worry, etc.

Research related to emotional intelligence and peer acceptance or social relationships with others produces research results that supported this research. Some of the results of research that have been carried out yielded results in the form of emotional intelligence having a relationship or connection with social acceptance [24], the contribution given to emotional intelligence greatly affects the amount of social acceptance among peers. The greater the level of emotional intelligence a person has, the greater he/she is accepted by the social environment in which he/she is [25].

The development of emotional intelligence has a positive impact that affects a person in developing relationships with others, which is whether he/she is accepted or not by his/her peers. This is directly proportional to the attitude and behavior shown by someone when he/she is accepted by his/her peers, because the support and presence of friends around could makes someone feel comfortableand can actualize themselves more optimally.

\section{CONCLUSION}

This study aims to describe the level of peer acceptance, the level of emotional intelligence, and the contribution of emotional intelligence to peer acceptance at Public Junior High School 14 Surakarta. Based on data analysis, it could be concluded that the level of student peer acceptance was relatively low, while the level of emotional intelligence was relatively high, besides that the level of emotional intelligence contributes to the level of peer acceptance by $15.8 \%$. Adolescents who have coaching and good skills in managing their emotions will be easier to be accepted in a relationship with their peers/clique. If they feel accepted in a group, it will have a positive impact on their daily life, both academically and non-academically. Conversely, if they are rejected, it will have a negative impact that will affect their daily lives. So that the existence of emotional intelligence can help adolescents in fostering good relationships with their peers.

\section{ACKNOWLEDGMENT}

This research has several shortcomings and limitations, one of which is that research is only conducted at one institution or school, so the data obtained is not necessarily a reference for generalization in a wider scope. Other researchers who are interested and want to conduct research on similar themes can develop emotional intelligence variables and peer acceptance variables in more depth. Retrieval of additional data can be done through observation and interviews with several students to get a more realistic picture of the data to be reviewed in the study, not only based on data taken with a questionnaire instrument. Similar research to be carried out is expected to cover several levels of education, such as elementary and high school levels.

\section{REFERENCES}

[1] Santrock, J. W. Perkembangan Anak: Edisi Kesebelas. Jilid 2. Jakarta: Erlangga. 2007

[2] Hurlock E. B. Psikologi Perkembangan. Jakarta: Erlangga, 2012

[3] Prayitno \& Amti, E. Dasar-dasar Bimbingan \& Konseling. Jakarta: PT. Rineka Cipta. 2013.
[4] Padmomartono, S. Konseling Remaja. Yogyakarta: Ombak. 2014.

[5] Octaviyana, I., Firman \& Daharnis, The contribution of social conflict with peers toward self confidence, Jurnal Internasional Bimbingan dan Konseling, vol. 1, pp. 10-14, October 2017.

[6] King, K. M., Mclaughlin, K. A, J. Silk, and Monahan, K.C. Peer Effects On Self-Regulation In Adolescence Depend On The Nature And Quality $O f$ The Peer Interaction, Development and Psychopathology, vol. 30, pp. 1389-1401, November 2017.

[7] Mappiare, A. Psikologi Remaja. Surabaya: Usaha Nasional. 1982.

[8] Rosida, E. R \& Astuti, T. P. Perbedaan Penerimaan Teman Sebaya Ditinjau Dari Tipe Kepribadian Ekstrovert Dan Introvert. Jurnal Empati, vol. 4, pp. 77-81, January 2015.

[9] Berndt, T. Child Development. United States of America: Holt Rinehart \& Winston Inc, 1992.

[10] Oberle, E. Social-Emotional Competence And Early Adolescents Peer Acceptance In School: Examining The Role Of Afternoon Cortisol. PloS ONE, vol. 13, pp. 1-12, February 2018

[11] Goleman, D. Kecerdasan Emosi untuk Mencapai Puncak Prestasi. Jakarta: PT Gramedia Pustaka Utama, 2003.

[12] Kurtoglu, M. Determination Of The Relationship Between Emotional Intelligence Level And Decision Making Strategies In Gifted Students. Journal for the Education of Gifted Young Scientists, vol. 6, pp. 1-16, March 2018.

[13] Vashiht, R.Singh, K. \& Sharma, S. Emotional Intelligence And Its Relationship With Conflict Management And Occupational Stress: A Meta-Analysis. Pacific Business Review International, vol. 11, pp. 30 38. October 2018

[14] Uno, H. B. Orientasi Baru dalam Psikologi Perkembangan. Jakarta: PT Bumi Aksara. 2010.

[15] Jesus, M. D., Wiyono, J \& Ardiyani V. M. Hubungan Kecerdasan Emosional Dengan Interaksi Sosial Pada Lansia Di Posyandu Tlogo Suryo Malang. Jurnal Ilmiah Keperawatan, vol. 3, pp. 810819, March 2018.

[16] Gallardo, L. O., Barrasa, A. \& Guevara-Viejo, F. Positive Peer Relationships And Academic Achievement Across Early And Midadolescence. Social Behavior and Personality: An International Journal, vol. 44, pp. 1637-1648, November 2016.

[17] Weyns, T., Colpin, H., Laet, S. D., Engels, M., \& Verschueren, K. Teacher Support, Peer Acceptance, And Engagement In The Classroom: A Three-Wave Longitudinal Study In Late Childhood. Journal Youth Adolescence, vol. 47, pp. 1139-1150, October 2017.

[18] Mullen, P. R., Gutierrez, D., \& Newhart, S. School counselors' emotional intelligence and its relationship to leadership. Professional School Counseling, vol. 21, pp. 1-12, June 2018.

[19] Razak, A., \& Jalal, N. M. Hubungan Antara Kecerdasan Emosional Dengan Kompetensi Kepribadian Guru. Jurnal Psikologi Talenta, vol. 4, pp. 69-79, September 2018.

[20] Putri, H. N., Nauli, F. A., \& Novayelinda, R. Faktor-Faktor Yang Berhubungan Dengan Perilaku Bullying Pada Remaja. Jurnal Online Mahasiswa, vol. 2, pp. 1149-1159, October 2015.

[21] Lestika, C. S. \& Kristian. Pengaruh metode latihan dan kecerdasan emosional terhadap hasil belajar mata diklat ilmu statika dan tegangan siswa kelas X SMK Negeri Binaan provinsi Sumatera Utara. Jurnal Education Building, vol 1, pp. 51-62, June 2015.

[22] Sánchez-Núñez, T. M., Medina, C. R \& Rubio, N. G. Gender Differences In Perceptive Emotional Adjustment Of Parents On Their Children's Emotional Intelligence., Scientific Research Publishing Psychology, vol. 9, pp. 124-143, January 2018.

[23] Herlinda, D. Warsidi \& Sulian, I. Hubungan kecerdasan emosi dengan kemampuan bersosialisasi siswa di lingkungan sekolah kelas VII SMP Negeri 03 Mukomuko. Jurnal Consilia, vol. 1, pp. 5058, December 2018

[24] Yuliantini, S. Hubungan Kecerdasan Emosi Dan Penyesuaian Sosial Dengan Kenakalan Remaja Pada Siswa SMP PGRI 7 Samarinda Seberang. Jurnal Psikoborneo, vol. 5, pp. 386-399, August 2017.

[25] Agustini, I. W. Sujana., \& Putra, I. K. A. Korelasi Antara Kecerdasan Emosional Dengan Interaksi Sosial Siswa Kelas V SD Gugus VI Pangeran Diponegoro Denpasar Barat. Jurnal Pedagogi dan Pembelajaran, vol. 2, pp. 131-140, May 2019. 